\title{
sciendo
}

\section{Perry T. Hamalis, Valerie A. Karras (eds.), Orthodox Christian Perspec- tives on War, Notre Dame, University of Notre Dame Press 2018, 402 p.}

\section{Ionuţ Biliuţă}

The emergence of the national states and churches impacted decisively on the future developments and views regarding various aspects of social and political life. One of these aspects related to the way in which states waged their wars and how various Christian denominations perceived their role during these wars. In their co-edited book, Perry A. Hamalis and Valerie A. Karras provide the reader with an array of informed theological opinions from various reputable theologians of the conceptual and Patristic underpinnings describing Orthodox Christianity's views regarding war. Unveiling, over time, the place war occupied in the Patristic and modern theological thought in Eastern Christianity, the editors dispute various heterodox claims from Orthodox milieus which incessantly preach the validity of the ,just war" theory among Orthodox Christians.

The book contains three parts. The first, entitled "Confronting the Present-Day Reality" (p. 13-61) addresses the current debates regarding the validity of theologizing about war from an Eastern Christian perspective. In his contribution named "The Ascetics of War: The Undoing and Redoing of Virtue" (p. 13-37), Aristotle Papanikolaou argues about the evil that war poses for Christian ethics from the perspective of theosis. Moreover, by disagreeing with several voices from the field of Orthodox theology (Fr. Andrew Webster, Perry T. Hamalis), Papanikolaou discredits the "just war" theory in Orthodox theology by emphasizing that contrary to the traditional teachings of the Orthodox Church, war as morally evil leaves its combatants with traumatic scars. According to Papanikolaou, war „opens up the body not to God, but to the inhabitation of the anti-God." (p. 18) By buttressing his views of St. Maximus the Confessor (†662 AD) and considering that "virtue is embodied deification" (p. 23), A. Papanikolaou reshapes veterans' war experiences according to Orthodox mystical tradition of the Holy Fathers and considers that "theologically, veterans are iconically charged to present the divine to each other even in the midst of, and because of, their shared suffering." (p. 29)

The next section, „Reengaging Orthodoxy's History and Tradition” (p. 61-251) comprises various contributions addressing multi-faceted aspects of the Orthodox tradition relating to war. This section engages with several

\footnotetext{
* Ionuț Biliuță, Gheorghe Șincai Institute for Social Sciences and the Humanities, Romanian Academy
}

RES 12 (2/2018), p. 290-293

DOI: $10.2478 /$ ress-2018-0024 
aspects of Christian history intertwined with warfare: the Old Testament's prophetic tradition and its symbolism as interpreted by the Fathers of the Church (Nicolae Roddy), the turbulent historical context in Roman-held Judea during Jesus Christ's life and the early first century AD Jewish traditions of war (John Fotopoulos), the assessments about waging war and the very moral nature of war raised by Origen $(† 253 \mathrm{AD})$ and the Cappadocian Fathers in late fourth century $\mathrm{AD}$ (Valerie A. Karras). The section also relates to the Western critique of the imperial strategy of war as present in the writings of Bishop Ambrose of Mediolanum (George E. Demacopoulos), the lived experience of martyrdom of Christian soldiers turned into the cult of the military saints in Orthodox Christianity (James C. Skedros), and how the Byzantines envisaged war through their theological lenses (Alexandros H. Kyrou, Elisabeth H. Prodromou).

The most important texts from this part are those authored by Valerie A. Karras and George E. Demacopoulos. While Karras argues that although "there was no single view on war and military service in the early and Byzantine Christianity" (p. 126), to the imperial complaints or the criticisms raised by various pagan thinkers such as Celsus that deemed Christians' refusal to take up arms as unpatriotic, according to Origen, early Christians acted as spiritual soldiers by "fighting against the root of violence, namely, evil." (p. 133) With the increasing Christianization of the Roman Empire and the edict of Emperor Theodosius II from 439 stating that only Christians had to serve in the military, things changed dramatically. Both Gregory of Nyssa $(\dagger 394 \mathrm{AD})$ and Basil the Great $(\dagger 379 \mathrm{AD})$ noticed this change in their subsequent writings. As Valerie A. Karras emphasizes, while other Cappadocians allegorized the chapters of the Old Testament speaking about the importance of violence and divine-sanctioned war, it was Basil the Great who in his Epistle 118, later on, canon 13, stated that killing someone on the battlefield was murder and the penance was three years of abstinence from communion. (p. 146).

On the other hand, in his text "Constantine, Ambrose and the Morality of War: How Ambrose of Milan Challenged the Imperial Discourse on War and Violence" (p. 159-193) Dr. Demacopoulos unveils the Western part of it as reflected in the texts of the Latin apologists and, most importantly, in the counter-imperial theology of Ambrose of Milan (†379 AD). Referring to the philosophical tradition of Cicero ( $† 43 \mathrm{BC}$ ) that implied the importance of imperium for the future Roman rule, the pacifist and anti-war views of the early Latin theologians, Demacopoulos argues in favor of a better reception by Orthodox theologians of Ambrose's anti-imperial reasonings as expressed in his writings. The author identifies eight princi- 
ples formulated in Ambrose's writings that express the position of the Latin Church in the fourth century AD: "(1) war must be defensive in nature, (2) agreements between enemies should be honored, (3) an army may not take an unfair advantage over its enemy, (4) mercy should be shown to those defeated, (5) clerics may not participate in the hostilities, (6) the institutional church does not get involved in war, (7) necessity can demand that one uses force in defense of the innocent and, (8) the courage of the soldier in the field pales in comparison to that of the martyr who willingly goes to his or her death without recourse to violence." (p. 170) Demacopoulos' assessments summarizing Ambrose's main ideas about Christians partaking in war and violence reveal a theologian eager to conserve peace by all means. Unlike his counterpart, the imperial bishop Eusebius of Caesarea (+33) $\mathrm{AD})$, the main architect of the imperial theology and the most vocal witness of the divine help received by the Constantinian dynasty in wars, Ambrose of Milan's treaty De officiis fails to praise military triumphs of emperors and relies on examples from Old Testament as the sole examples of God's intervention during conflicts. Moreover where Eusebius recognizes the execution of Emperor Licinius by Constantine the Great (325 AD) as ,just punishment," Ambrose recommends that the rulers show mercy towards those defeated. (p. 170)

The last section, "Constructive Directions in Orthodox Theology and Ethics" (p. 251-361), takes the theological discussion about war and its relevance up to the present day. Encompassing various theoretical underpinnings (ethics, systematic theology, religious philosophy), the texts from this last part of the book discuss the contemporary developments in Orthodox theology regarding war, capital punishment, and the just or unjust moral nature of recent conflagrations. From the already accepted assumption that war is evil, Peter C. Bouteneff (p. 251-275) explores the Patristic and theological views regarding war perceived as a "lesser good" through the concept of divine providence as the starting point for a future Orthodox theology of war at the intersection between good and evil.

Expanding the discussion about the relevance of divine providence in the context of a future Orthodox theology of war, in his text entitled "A Helper of Providence: Justified Providential War in Vladimir Solov'ev" (p. 277-315) Brandon Gallaher turns to Solov'ev's “justified providential war" as a form of a lesser evil, allowed by God's providence. As a necessary tool, the war would have enabled the instauration of the divine kingdom on earth. Although the Russian philosopher accredited the idea of „justifiable war," nevertheless, as Brandon Gallaher notes, besides his absolute idealism and Platonic-influenced moral relativism, Solov'ev failed to deliver a plausible explanation to a century of perpetual war. (p. 307) 
The book ends with two contributions penned by Gayle Wolschak named "War, Technology, and the Canon Law Principle of Economia" (p. 315-335) and Perry T. Hamalis, "Just Peacemaking and Christian Realism: Possibilities for Moving Beyond the Impasse Beyond the Christian War Ethics" (p. 335-361). While Dr. Wolschak explores the adventures of the theological concept of economia applied when Christians go to war or even to the reality of war itself, Perry T. Hamalis provides answers to questions related to the participation of Orthodox Christians in contemporary conflicts.

Bringing together some of the most reputable voices in contemporary Orthodox theology in the West, the volume exceeds the reader's expectations and has very few flaws. Nevertheless, one can argue when reading the whole volume that, though elegantly and brilliantly argued, most of the contributions from this volume fail to connect to the actual reality of war. By engaging with war as a concept and less as a social reality of our days, the edited volume tends to elude the actuality of war.

Diversely and sophisticated, the book stands out as a magnificent piece of scholarship and a welcome contribution to the current discussions in the field of moral and theological reflection about war. As one of the first comprehensive studies of the Christian tradition and contemporary rationale on modern conflicts and violence, the volume edited by Perry $\mathrm{T}$. Hamalis and Valerie A. Karras will be an essential reading in the ecumenic curricula for professors, graduate and undergraduate students, and those readers interested in the conundrum of violence intertwined with Christian theology. It would also be a mandatory reference for teaching graduate and undergraduate courses of Systematic Theology, Moral Theology, History of Christian Tradition or Ethics. 